\title{
URGENSI PERLINDUNGAN BENDA BERSEJARAH DI INDONESIA BERDASARKAN HUKUM HUMANITER INTERNASIONAL
}

\author{
Taufik Rachmat Nugraha*
}

\author{
Fakultas Hukum, Universitas Padjadjaran \\ Jl. Raya Bandung Sumedang KM.21, Hegarmanah, Kec. Jatinangor, Kabupaten Sumedang, \\ Jawa Barat, 45363
}

\begin{abstract}
Indonesia has various historical cultural properties from Megalithic to Colonial Era. However, their existence are in danger due to the armed conflict which may break out in unspecified and unpredictable time and place. Therefore, this issue has to be the main concern in regard to the existence of Indonesian historical Cultural Properties. Meanwhile, Indonesia as a member of The Hague Convention 1954 and UNESCO Convention 1977 still does not have a particular regulation regarding the protection of historical properties during armed conflict. This Article will examine the Indonesia's urgency in creating particular regulation through National Legislation and also inserting enhanced protection to the cultural properties which are considered great importance for all peoples. Hence, these cultural properties will have international protection during armed conflict.
\end{abstract}

Keywords: international humanitarian law, The Hague Convention 1954, Indonesian cultural heritages protection.

\section{Intisari}

Indonesia memiliki keanekaragaman benda budaya yang bersejarah dari peninggalan era megalitikum hingga kolonial. Namun, eksistensi benda budaya tersebut terancam oleh konflik bersenjata dan konflik bersenjata dapat saja terjadi kapanpun dan dimanapun dan juga tidak seorangpun dapat memprediksinya, persoalan ini yang harus menjadi pertimbangan utama karena benda budaya akan sangat rentan ketika terjadi bila konflik bersenjata terjadi di Indonesia. Sementara itu, Indonesia merupakan negara peserta dari Konvensi Den-Haag 1954 dan Konvensi UNESCO 1977, hanya saja hingga saat ini Indonesia belum memiliki peraturan khusus terkait perlindungan benda budaya pada masa konflik bersenjata. Artikel ini akan menguji urgensi Indonesia untuk membuat peraturan khusus dan memasukan pengaturan enhanced protection pada benda budaya yang dinilai memiliki nilai keluhuran bagi umat manusia agar mendapat perlindungan secara internasional jika terjadi konflik bersenjata di masa depan.

Kata Kunci: hukum humaniter internasional, Konvensi Den-Haag 1954, perlindungan benda budaya Indonesia.

\section{Pokok Muatan}

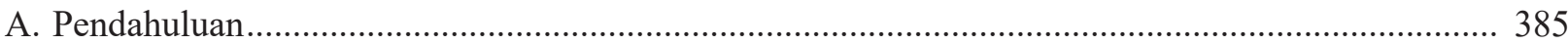

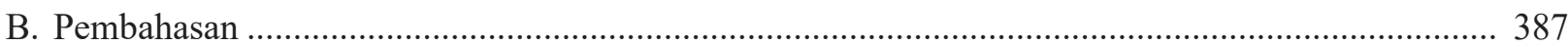

1. Perlindungan Benda Cagar Budaya dalam Konteks Internasional ............................................ 387

2. Perkembangan Pengaturan Benda Budaya pada Masa Konflik Bersenjata.................................. 392

3. Instrumen Hukum Nasional Mengenai Perlindungan Benda Budaya ........................................ 394

4. Urgensi Perlindungan Benda Cagar budaya pada Masa Konflik Bersenjata bagi Indonesia ....... 396

5. Implementasi Perlindungan Benda Cagar Budaya pada Masa Damai melalui Pembentukan

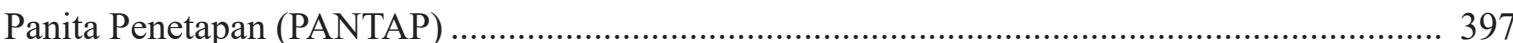

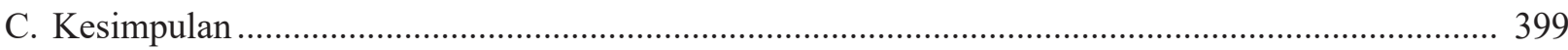

Alamat Korespondensi: taufik18004@mail.unpad.ac.id. 


\section{A. Pendahuluan}

Benda budaya memiliki kerentanan serius jika terjadi konflik bersenjata baik dalam konflik bersenjata internasional maupun non-internasional. Benda budaya merefleksikan kehidupan, sosial, dan sejarah daripada masyarakat di suatu tempat itu sendiri. Pelestariannya dapat membantu untuk membangun kembali sebuah masyarakat, mengembalikan identitas masyarakat tersebut, yang akan menghubungkan dengan sejarahnya dimasa silam dengan kehidupan dimasa kini. Pada benda budaya dari setiap peradaban memiliki kontribusi besar sebagai bagian dari warisan umat manusia. Dengan demikian, kehancuran pada cagar budaya merupakan suatu malapetaka bagi umat manusia. ${ }^{1}$

Ada sebuah kekhawatiran berupa ancaman hilangnya benda budaya mengingat begitu banyaknya benda budaya di Indonesia jika terjadi konflik bersenjata, sebagai contoh pada kasus Ahmad Al-Ahmadi terkait penyerangan langsung dan penghancuran kawasan situs Timbuktu yang telah mendapatkan perlindungan internasional sejak tahun 1988. ${ }^{2}$ Ahmad Al-Ahmadi dalam persidangannya di International Criminal Court (selanjutnya disebut ICC) diketahui dengan sengaja memberikan instruksi untuk menghancurkan mausoleum, masjid, dan manuskrip berharga selama masa konflik bersenjata yang melanda Mali pada tahun 2012. ICC memutuskan bahwa Ahmad Al-mahdi bersalah dan dihukum penjara selama sembilan tahun dan denda sebanyak 2.700.000 Euro, yang terdiri dari ganti rugi kerusakan pada benda cagar budaya sebesar 91.000 Euro, dampak kerugian secara ekonomi sebesar 2.120.000 Euro, dan ganti rugi secara moral sebesar 483.000 Euro. $^{3}$

Berdasar contoh di atas, Indonesia memerlukan sebuah perlindungan internasional pada benda budayanya, karena situs benda budaya menjadi sangat rentan menjadi sasaran penghancuran secara langsung maupun penjarahan ketika terjadi konflik bersenjata internasional dan non-internasional. Mengingat juga Indonesia memiliki ribuan situs cagar budaya yang sebenarnya belum memiliki perlindungan secara internasional melalui pendaftaran kepada UNESCO.

Perlindungan bagi benda budaya terbagi atas dua kategori utama dalam Konvensi Den Haag 1954 yaitu umum dan khusus, dan satu kategori tambahan yakni enhanced protection dalam Protokol kedua 1999 dari Konvensi Den Haag 1954. Perlindungan umum artinya benda budaya yang dilindungi oleh Konvensi Den Haag 1954 yang merupakan benda budaya yang memiliki nilai keluhuran budaya bagi warisan umat manusia, yang tidak boleh diserang pada masa konflik bersenjata. Perlindungan khusus yaitu benda budaya yang dilindungi dalam Konvensi Den Haag 1954 sama seperti perlindungan umum, namun praktik pelepasan status perlindungannya harus ditetapkan oleh perwira setingkat komandan divisi dan telah didaftarkan dalam International register of cultural property under special protection. ${ }^{4}$ Berdasarkan Protokol kedua 1999 dari Konvensi Den Haag 1954 yaitu benda budaya yang telah diregistrasikan dalam list of cultural property under enhanced protection, merupakan benda budaya yang sangat penting bagi kemanusiaan atau dalam termanya tersendiri disebut sebagai "greatest importance for humanity", dan telah mendapatkan perlindungan domestik setinggi-tinggiya.

Pentingnya pendaftaran dan pemberian perlindungan bagi benda budaya pada masa damai sudah diamanatkan dalam Pasal 3, Konvensi Den Haag 1954, yang isinya menugaskan para pihak peserta dalam perjanjian tersebut untuk mendaftarkan dan memberikan perlindungan kepada benda cagar budaya pada masa damai. ${ }^{6}$

\footnotetext{
UNESCO, "Why is it necessary to protect cultural property in the event of armed conflict and/or occupation", http://www.unesco.org/new/en/ culture/themes/armed-conflict-and-heritage/convention-and-protocols/frequently-asked-questions/\#c287372 diakses 8 Oktober 2018.

ICC Document (2017), "Situation in the Republoc of Mali in the Case of the Prosecutor v. Ahmad Al-faqi Al Mahdi", https://www.icc-cpi.int/ CourtRecords/CR2017 05117.PDF, diakses 9 Oktober 2018.

Ibid.

Article 13, Second Protocol to the Hague Convention of 1954 for the Protection of Cultural Property in the Event of Armed Conflict (1999). Ibid, Article 10

Kevin Chamberlain, 2006, Casualties of Armed Conflict: Protecting Cultural Property. In Yearbook of Humanitarian Law Volume 17, 2014, compiled by Terry D. Gill (eds) Asser Press, The Hague, hlm. 193.
} 
Selain pada Pasal 3 terdapat juga dalam Pasal 7 ayat 1 dan ayat 2 Konvensi Den Haag 1954 menyatakan bahwa Negara harus memasukkannya dan memperkenalkannya ke dalam peraturan militer atau instruksi-instruksi tentang ketentuan yang dapat menjamin ketaatan terhadap budaya dan benda budaya di setiap Negara-negara anggota.

Indonesia memiliki begitu banyak cagar budaya di dalamnya, dari berbagai peradaban mulai dari situs megalitikum di Bondowoso yang berasal dari tahun 1000-100 SM yang peninggalannya masih bisa dilihat dan dinikmati hingga hari ini. ${ }^{7}$ hingga keindahan bangunan tua di kota-kota besar di Indonesia yang juga tentu memiliki nilai sejarah yang tidak kalah besarnya, seperti Gereja Blenduk di Semarang dan museum Gajah di Jakarta.

Sebagai fakta, pemerintah Indonesia sendiri sudah meratifikasi konvensi Den Haag tersebut pada tahun 1966 dengan dikeluarkannya Kepurusan Presiden Tahun 1966 tentang Pengesahan Konvensi untuk Melindungi Milik Kebudayaan dalam Waktu Persengketaan Bersenjata $1954,{ }^{8}$ yang isinya menyatakan bahwa Indonesia tidak berkeberatan dengan isi dari konvensi tersebut, dan menerima seluruh isi dari konvensi Den Haag 1954, karena pemerintah Indonesia pada saat itu menyadari pentingnya memberikan perlindungan khusus pada situs-situs cagar budayanya.

Setelah Indonesia resmi mengaksesi Konvensi Den Haag 1954 pada tahun 1966, dibuatlah UndangUndang Nomor 5 Tahun 1992 tentang Benda Cagar Budaya dan Undang-Undang Nomor 11 Tahun 2010 tentang Cagar Budaya (selanjutnya disebut UU No. 11 Tahun 2010), yang isinya meliputi kategorisasi benda cagar budaya, identifikasi benda cagar budaya, tata cara registrasi benda cagar budaya, dan perlindungan benda cagar budaya, namun tidak memuat jenis-jenis cagar budaya yang harus diregistrasikan untuk mendapatkan perlindungan khusus di bawah hukum internasional.

Berdasarkan data yang dihimpun dari Direktorat Pelestarian Cagar Budaya dan Permuseuman Tahun 2013, dapat diketahui, bahwa jumlah cagar budaya di Indonesia mencapai angka 66.513 cagar budaya, yang terdiri atas 54.398 cagar budaya bergerak dan 12.115 cagar budaya tidak bergerak, yang tersebar di seluruh pelosok tanah air. ${ }^{9}$ Dari jumlah tersebut, sudah dipelihara sebanyak 1.895 cagar budaya, dengan 2.988 juru pelihara. Cagar budaya yang telah dipugar berjumlah 643 cagar budaya, 146 cagar budaya telah dipugar, dan 983 cagar budaya telah ditetapkan oleh Menteri Pendidikan dan Kebudayaan. ${ }^{10}$

Diantara sekian banyaknya situs yang diregistrasi hingga tahun 2017 hanya terdapat empat situs yang sudah didaftarkan ke UNESCO untuk mendapatkan perlindungan internasional, yaitu diantaranya: Candi Borobudur, komplek Candi Prambanan, situs purbakala Sangiran dan yang terbaru ialah kawasan sistem subak di Bali. ${ }^{11}$ Namun, beberapa benda cagar budaya yang juga memiliki nilai keluhuran bagi umat manusia belum diregistrasikan untuk mendapat perlindungan internasional.

Berdasarkan fakta realitas dan fakta hukum di atas, benda bersejarah di Indonesia saat ini memiliki ancaman terhadap eksistensinya, ancaman tersebut berasal dari sumber alamiah dan tangan manusia. Sumber alamiah tersebut umumnya dikenal dengan pelapukan pada benda bersejarah. Sementara itu, yang dimaksud dengan ancaman oleh tangan manusia umumnya dilakukan dengan cara penghancuran secara sengaja, penjarahan, dan jual-beli ilegal. Hal tersebut dapat terjadi dalam konteks pada masa damai dan juga pada masa konflik bersenjata.

\footnotetext{
Fakultas Hukum Universitas Indonesia, "Perlindungan hukum terhadap cagar budaya di Indonesia", http://law.ui.ac.id/v3/4385-2/, diakses 8 Oktober 2018

8 Arlina Permanasari, "Indonesia dan konvensi Den Haag 1954”, https://arlina100.wordpress.com/2008/12/18/indonesia-dan-konvensi-denhaag-1954/\#more-740, diakses 9 Oktober 2018.

DITPCBM, “Cagar Budaya”, https://kebudayaan.kemdikbud.go.id/ditpcbm/cagarbudaya/, diakses 10 Januari 2019

Ibid.

World heritage list/Indonesia, https://whc.unesco.org/en/list/?search=indonesia, diakses 8 Oktober 2018.
} 
Pada masa damai UUNo. 11 Tahun 2010 sudah memberikan ancaman hukuman pidana pada siapa saja yang dengan sengaja merusak, memindahkan atau menghilangkan benda cagar budaya. Dalam konteks terjadinya konflik bersenjata UU No. 11 Tahun 2010 belum mencakup permasalahan tersebut, karena secara garis besar UU No. 11 Tahun 2010 dibuat untuk melindungi benda cagar budaya pada masa damai. Dengan demikian, artikel ini bertujuan mengupas urgensi terkait pengaturan benda cagar budaya pada masa konflik bersenjata perlu segera diterapkan di Indonesia.

\section{B. Pembahasan}

1. Perlindungan Benda Cagar Budaya dalam Konteks Internasional

a. Sejarah Perkembangan Perlindungan Benda Cagar Budaya Pra 1954

Perlindungan benda cagar budaya khususnya pada masa konflik bersenjata menjadi sebuah keharusan bagi Indonesia. Hal tersebut berkaitan dengan fakta bahwa Indonesia menyimpan begitu banyak benda cagar budaya yang hingga saat ini banyak diantaranya yang belum mendapatkan perlindungan secara internasional maupun nasional. Perlindungan benda budaya pada masa konflik bersenjata dalam bingkai internasional telah diatur seiring dengan perkembangan tata cara berperang umat manusia.

Konvensi Den Haag yang pertama tahun 1899 mengenai tata cara berperang memberikan penjelasan tentang larangan bagi pasukan militer untuk melakukan penyitaan dan perampasan di wilayah yang sedang dikuasai. Konvensi Den Haag 1899 menekankan bahwa benda-benda seni, benda yang berhubungan dengan unsurunsur keagamaan, rumah sakit, atau tempat yang dimana didalamnya ada orang yang terluka dan sakit, selama tempat tersebut tidak menjadi bagian dari objek militer, maka bangunan tersebut tidak boleh diserang. ${ }^{12}$ Dalam Pasal 27 juga sudah mulai menerangkan tentang penggunaan tanda pembeda, yakni ketika benda tersebut terancam diserang oleh pasukan penyerang, dan bangunan tersebut bukanlah bagian dari objek militer, maka orang yang didalam bangunan tersebut harus menunjukan tanda pembeda yang dapat terlihat dengan jelas, dan selain itu memberikan pemberitahuan kepada pasukan penyerang terkait penggunaan tanda pembeda tersebut.

Pada tahun 1907 Konvensi Den Haag kembali diadakan, pada konvensi Den Haag 1907 pengaturan mengenai perlindungan benda budaya sudah terbilang selangkah lebih maju. Dinyatakan oleh Pasal IV Konvensi Den Haag 1907 bahwa benda objek yang merupakan representasi dari keagamaan, kegiatan sosial, pusat pendidikan, benda seni, dan ilmu pengetahuan harus dihormati oleh militer. Perlindungan didalam konvensi Den Haag 1907 Pasal IX kembali menegaskan kembali bahwa objek yang tidak boleh diserang yaitu seperti tempat suci (keagamaan), monumen bersejarah, rumah sakit, dan tempat yang menampung orang sakit. Dalam Konvensi Den Haag 1907 dijelaskan bahwa ada konsekuensi hukum yang akan diberikan kepada individu yang memberikan perintah untuk menyerang tempat bersejarah tersebut. ${ }^{13}$ Selain itu perlindungan benda sejarah dalam Konvensi ini sudah merinci lambang yang menandakan benda budaya yang dilindungi dibawah Konvensi Den Haag 1907.

Pasca perang dunia ke- I perlindungan benda budaya mejadi perhatian utama oleh dunia Internasional, permasalahan

Article 27, 1899 the Hague Convention.

13 Article 56, 1907 the Hague Convention No. IV; laws and customs of war on land. 
ini dibuktikan dengan dibuatnya Pakta Roerich 1935 dengan benda budaya sebagai pembahasan utama. Dalam Pakta Roerich 1935 perlindungan benda budaya yakni benda budaya mencakup museum bersejarah, pusat ilmu pengetahuan benda-benda seni pusat Pendidikan harus dihormati dan dilindungi oleh para pihak yang sedang berkonflik. ${ }^{14}$ Dalam Pakta Roerich 1935 penggunaan lambang pembeda sudah resmi diatur penggunaannya dalam Pasal III Pakta Roerich. ${ }^{15}$ Menjadi patokan resmi bahwa lambang tersebut diberikan kepada objek-objek yang tidak boleh diserang oleh kekuatan militer seperti yang tercantum dalam pasal $1^{16}$. Pelanggaran yang dilakukan oleh pasukan militer dengan tetap menyerang objek yang telah memasang lambang Roerich tidak diatur mengenai sanksi-nya, dan bagaimana akibat setelahnya. dengan adanya kekurangan tersebut maka dibuat lagi aturan yang kali ini benar-benar menutupi kekurangan-kekurangan yang terdapat pada perjanjian terdahulu, yaitu dengan membuat Konvensi Den Haag 1954. ${ }^{17}$

b. Konvensi Den Haag 1954 tentang Perlindungan Benda Budaya pada Masa Konflik Bersenjata

Perang dunia ke-II menimbulkan luka yang sangat mendalam bagi dunia dikarenakan kehilangan yang begitu besar terhadap puluhan juta nyawa dan juga hilang atau rusaknya benda cagar budaya sebagai akibat dari konsekuensi perang besar. PDII menimbulkan efek traumatis yang sangat mendalam bagi dunia yang dimana negara- negara berkomitmen untuk mencegah hal serupa terulang kembali dimasa depan. Sesaat setelah PD-II berakhir negara-negara bersepakat untuk segera membuat piagam yang memuat aspek-aspek dasar kehidupan manusia, seperti; Piagam Hak Asasi Manusia 1948, Konvensi tentang genosida tahun 1948, dan empat Konvensi Jenewa 1949. Perjanjian tersebut lahir atas dasar rasa kehilangan yang sangat mendalam selama PD-II, dan mejelaskan posisi komunitas intenasional terkait isu kemanusiaan sebagai agenda utama. ${ }^{18}$ Sebagai langkah kongkrit perlindungan benda cagar budaya maka dibuatlah Konvensi Den Haag 1954 melalui usulan UNSECO yang mulai dibuka untuk ditandatangani mulai bulan Mei 1954.

Konvensi Den Haag 1954 mengadopsi dari Pakta Roerich 1935 mengenai perlindungan benda cagar budaya dan lambang pembeda. Selain keterikatan dengan Pakta Roerich 1935, Konvensi Den Haag 1954 juga memiliki latar belakang sejarah mengenai pembentukannya yang merujuk kepada Konvensi ke-empat dari Konvensi Jenewa. Isi dari Konvensi ke-empat dari Konvensi Jenewa 1949 menjelaskan tentang perlindungan properti pada saat dikuasai oleh pihak pengokupasi, bahwa disebutkan pengahancuran terhadap properti pribadi, rumah sakit, properti milik negara, adalah dilarang kecuali objek-objek tersebut dibutuhkan sebagai kebutuhan militer yang tidak dapat dihindarkan. Terdapat banyak sekali korelasi antara Konvensi ke-empat dari Konvensi Jenewa ini dengan Konvensi

Lihat Article 1, 1935 Roerich Pact and the Banner of Peace.

Lihat Article 3, 1935 Roerich Pact and the Banner of Peace.

6 Friederich T Schipper, et al., "A Concise Legal History of the Protection of Cultural Property in the Event of Armed Conflict and a Comparative Analysis of the 1935 Roerich Pact and the 1954 Hague Convention in the Context of the Law of War", Archaeologies: Journal of the World Archeological Congress, Vol.9, Issue 1, April 2013, hlm. 201

17 Mark C. Driver, "The Protection of Cultural Property During Wartime", Review of European Community and International Environmental Law, Vol. 9, Issue 1, April 2003, hlm. 1-12.

18 Kevin Chamberlain, 2006, Casualties of Armed Conflict: Protecting Cultural Property. In Yearbook of Humanitarian Law Volume 17, 2014, compiled by Terry D. Gill (eds) Asser Press, The Hague, hlm. 191. 
Den Haag 1954 termaksud didalammnya peraturan mengenai lambang pembeda. ${ }^{19}$

Konvensi Den Haag 1954 menekankan pada perlindungan benda cagar budaya yang dapat dilihat pada mukadimah dari konvensi ini "benda budaya telah menderita kerugian besar selama konflik-konflik bersenjata belakangan ini dan bahwa karena perkembangan-perkembangan Teknik berperang, benda budaya dalam bahaya kerusakan yang mengikat, kehilangan benda budaya merupakan sebuah kerugian besar terhadap warisan umat manusia, karena setiap orang membuat kontribusi terhadap budaya dunia, dan juga pemeliharaan benda budaya harus dilakukan dalam taraf nasional maupun internasional yang mengaturnya pada masa damai. Melihat dari isi mukadimah tersebut diyakinkan tujuan utama dari Konvensi Den Haag 1954 yakni berusaha menyeimbangkan antara kepentingan militer dan kemanusiaan khususnya yang terkait dengan perlindungan benda budaya. ${ }^{20}$

Bagian utama Konvensi Den Haag 1954 terdiri dari pengertian benda cagar budaya, bagaimana perlindungannya, pemberian status perlindungan umum dan khusus, pengaturan penggunaan lambang pembeda, dan proses pelepasan status perlindungan khusus pada masa konflik bersenjata. Bagianbagian tersebut merupakan jawaban harus adanya keseimbangan antara kepentingan militer disaat konflik bersenjata dan perlindungan benda cagar budaya pada masa konflik bersenjata.

Didalam perkembangan perjanjian yang memuat perlindungan benda cagar budaya dari masa Lieber Code 1863 hingga
Pakta Roerich 1935, tidak pernah sekalipun mencantumkan apa itu benda cagar budaya, terlebih lagi kata monumen bersejarah baru muncul dalam Konvensi ke-IV dari Konvensi Den Haag 1907. Selebihnya konvensikonvensi tersebut hanya menyebutkan objek apa yang tidak boleh diserang oleh pasukan militer ketika terjadi konflik bersenjata "pusat pendidikan, museum, pusat seni, rumah sakit atau tempat yang berisi orang yang terluka dan sakit tidak boleh diserang" hal tersebut belum secara jelas mengisyaratkan bahwa benda cagar budaya merupakan suatu kesatuan objek yang terpisah dari pengertian tersebut. Baru pada Konvensi Den Haag 1954 pengertian benda cagar budaya diberikan, yakni dalam pasal I Konvensi Den Haag 1954. Benda budaya yang bergerak maupun tidak bergerak yang mempunyai kepentingan besar terhadap warisan umat manusia. Memiliki beberapa kategori yaitu; monumen-monumen arsitektur, seni dan sejarah yang bersifat keagamaan atau secular, dan situs arkeologi. Benda budaya tidak hanya tercakup kepada hal-hal diatas namun juga bangunan yang digunakan sebagai tempat memelihara benda budaya.

c. Kewajiban Negara Peserta pada Masa Damai

Kewajiban negara peserta pada masa damai yaitu, membuat pemetaan/peraturan mengenai perlindungan benda-benda budaya yang berada di wilayahnya yang mana benda budaya tersebut dapat terancam ketika masa konflik bersenjata, ${ }^{21}$ hal tersebut dapat berupa sosialisasi dan diseminasi kepada seluruh masyarakat dan personil pemerintahan yang terkait dengan perlindungan benda budaya

19 Lihat Kevin Chamberlain, the distinctive emblem with blue and white shield, devise by contracting parties as the symbol of the protection of cultural property, was intended to perform the same role cultural property as did the Red Cross and Red Crescent for person protected by the Genève Convention, dalam Kevin Chamberlain, 2006, Casualties of Armed Conflict: Protecting Cultural Property. In Yearbook of Humanitarian Law Volume 17, 2014, compiled by Terry D. Gill (eds) Asser Press, The Hague, hlm. 194.

$20 \quad$ Ibid, hlm 195

21 Pasal 3, Konvensi Tentang Perlindungan Benda Cagar Budaya Pada Masa Konflik Bersenjata Den-Haag, 1954. 
pada masa damai dan masa konflik bersenjata, ${ }^{22}$ agar benda kehancuran benda budaya dapat diminimalisir semaksimal mungkin.

d. Kewajiban Negara Peserta pada Masa Konflik Bersenjata

Ketika terjadi konflik bersenjatamaka para negara peserta wajib untuk menghormati benda-beda budaya di wilayahnya, dan juga diwilayah pihak yang menjadi musuh. Seperti tidak boleh menyerang benda cagar budaya yang memiliki lambang perlindungan dengan sengaja. Penyerangan benda budaya yang memiliki lambang perlindungan hanya boleh dilakukan ketika objek benda budaya tersebut berubah menjadi objek militer pihak lawan, dan atau objek benda budaya tersebut tidak dapat dihindari penggunaannya sebagai objek militer sebagai bagian dari komando pertahanan dan strategi. ${ }^{23}$

Dalam hal ini Konvensi Den Haag memperlihatkan kesinambungan antara perlindungan benda budaya dan kepentingan militer sebagai bagian yang tidak bisa dipisahkan. Benda budaya yang sudah dalam penguasaan pihakmusuh tetapharus dihormati dan dijaga, serta pihak yang menguasai benda budaya tersebut wajib mengijinkan personil yang menjaga benda budaya tersebut untuk tetap melakukan tugasnya, ${ }^{24}$ di Indonesia personil yang dimaksud adalah Polisi Khusus Cagar Budaya (POLSUS-CB) yang memiliki kewenangan pengawasan dan perlindungan terhadap benda cagar budaya. ${ }^{25}$

e. Perlindungan Umum dan Perlindungan

Khusus pada Benda Budaya

Terdapat dua jenis perlindungan dari Konvensi Den Haag 1954 yaitu, perlindungan yang bersifat umum dan perlindungan yang bersifat khusus. Perlindungan yang bersifat umum yaitu berupa larangan terhadap penyerangan benda budaya yang dimana benda budaya tersebut bukan menajdi objek militer. Perlindungan yang bersifat umum ditandai dengan pemberian lambang pembeda. ${ }^{26}$

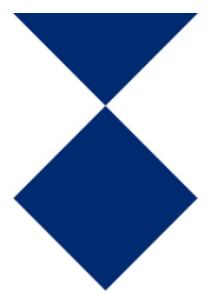

\section{Gambar 1. Lambang Perlindungan Umum Dalam Konvensi Den Haag 1954}

Sumber: Konvensi Tentang Perlindungan Benda Cagar Budaya Pada Masa Konflik Bersenjata Den-Haag, 1954.

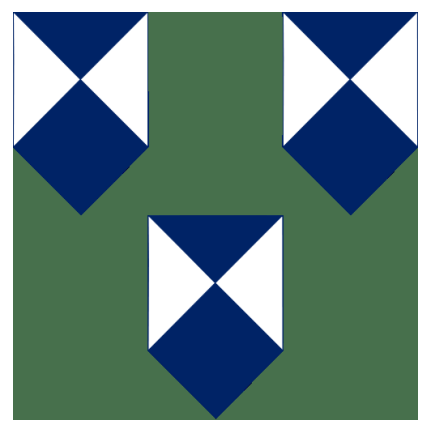

\section{Gambar 2. Lambang Perlindungan Khusus Dalam Konvesi Den Haag 1954}

Sumber: Konvensi Tentang Perlindungan Benda Cagar Budaya Pada Masa Konflik Bersenjata Den-Haag, 1954.

DITPCBM, "Diklat PPNS Cagar Budaya 2019: Kaitannya Dengan Perlindungan Cagar Budaya di Indonesia", https://kebudayaan.kemdikbud. go.id/ditpcbm/diklat-ppns-cagar-budaya-2019-kaitannya-dengan-perlindungan-cagar-budaya-di-indonesia/, diakses 26 November 2019.

26 Lambang pembeda perlindungan umum: satu buah perisai terbagi oleh dua segitiga secara vertikal, bagian atas bawah terdiri dari warna biru, dan bagian kanan-kiri terdiri dari warna putih. Dalam Pasal 16, Konvensi Tentang Perlindungan Benda Cagar Budaya Pada Masa Konflik Bersenjata Den-Haag, 1954. 
Sementara perlindungan yang bersifat khusus ialah pemberian perlindungan terhadap benda budaya yang terbatas melalui pendaftaran registrasi perlindungan khusus. ${ }^{27}$ Perlindungan benda budaya yang terbatas yang dimaksud adalah, benda budaya yang memiliki nilai-nilai keluhuran warisan bagi umat manusia, jauh dari objek militer, maka tidak semua benda budaya dapat diberikan perlindungan khusus. Benda budaya yang diberikan perlindungan khusus akan mendapatkan lambang perlindungan khusus. ${ }^{28}$

f. Pelepasan Status Perlindungan Benda Budaya

Poin utama dari bentuk perlindungan kepada benda budaya umum maupun khusus yang paling konkrit adalah pelepasan status perlindungan benda budaya pada masa konflik bersenjata. Pelepasan status perlindungan benda budaya merupakan hal yang penting dan harus dilakukan ketika benda budaya yang telah mendapatkan perlindungan berubah menjadi objek militer. Perubahan status benda budaya menjadi objek militer yang dimaksud ialah, ketika benda budaya tersebut digunakan sebagai barak militer, pusat pertahanan militer, penyimpanan amunisi militer, dan kegiatan yang terhubung langsung dalam gerakan militer, maka status perlindungannya dapat dimintakan untuk dicabut. Dalam hal ini jika militer akan menggunakan benda budaya yang sudah mendapat perlindungan akibat dari kepentingan militer yang tidak dapat dihindari maka akan ada sebuah proses yang harus ditempuh, proses pelepasan tersebut harus dilakukan oleh setidaknya komandan regu divisi atau yang diatasnya jika memungkinkan. ${ }^{29}$ Pelepasan status perlindungan benda budaya oleh tingkat komandan divisi atau yang diatasnya berkaitan erat dengan pengaturan strategi militer, mereka yang dianggap mengetahui strategi militer dan yang berhak mengeluarkan perintah bagi pasukannya pada masa konflik bersenjata. Pelepasan status perlindungan benda budaya tersebut wajib diberitahukan kepada Komisaris Jendral untuk benda budaya.

g. Konsekuensi Hukum Terhadap Pelanggaran Konvensi Den Haag 1954

Setiap benda budaya yang telah mendapatkan perlindungan tidak boleh serta merta diserang jika benda budaya tersebut bukan merupakan bagian dari objek militer. Pada masa konflik bersenjata para pihak harus mengetahui betul tentang mana benda budaya yang memiliki perlindungan dan benda budaya yang tidak memliki perlindungan. Hal ini akan berkaitan erat dengan pasal 25 dari Konvensi Den Haag 1954, bahwa ketika masa damai negara peserta harus mensosialisasikan kepada pasukan militernya tentang benda budaya yang mendapatkan perlindungan umum maupun khusus. Pada dasarnya benda budaya tidak boleh diserang, namun dalam hal ini benda budaya yang telah mendapatkan perlindungan umum dan khusus memiliki sebuah imunitas tersendiri, berkaitan dengan penggunaannya oleh militer yang harus ditetapkan oleh komandan divisi atau diatasnya, adanya kewajiban untuk tetap memelihara ketika benda budaya yang memiliki perlindungan tersebut jatuh kepada pihak lawan, dan adanya konsekuensi hukum jika salah satu pihak mengabaikan isi dari Konvensi Den Haag 1954 dengan menyerang benda budaya diluar alasan sebagai objek militer. Dalam Pasal 28 dari Konvensi Den 
Haag 1954 menyebutkan bahwa, Pihak-Pihak Peserta Agung berusaha untuk melakukan, dalam kerangka kerja yurisdiksi kriminal mereka, semua langkah- langkah yang diperlukan untuk menuntut dan mengenakan sanksi pidana atau sanksi disiplin terhadap setiap orang, apapun kewarganegaraannya, yang melakukan atau menyuruh melakukan suatu pelanggaran terhadap Konvensi ini.

\section{Perkembangan Pengaturan Benda Budaya} pada Masa Konflik Bersenjata

a. Protokol Pertama Den Haag 1954 terkait Perlindungan Benda budaya Pada Masa Konflik Bersenjata

Setelah perumusan Konvensi Den Haag pada bulan mai 1954, negara-negara peserta konvensi bersepakat untuk membuat suatu Protokol yang mengatur pengembalian benda budaya dari wilayah yang sebelumnya diduduki atau diokupasi. Protokol ini lahir dilatar belakangi dari dikirimnya harta nasional milik Polandia pada saat Polandia mulai dianeksasi oleh Jerman pada tahun 1939 yang berakhir di Kanada dengan latar belakang sebagai tindakan pencegahan teradap musnahnya harta nasional milik Polandia. ${ }^{30}$

\section{Protokol Pertama dari Konvensi}

Den Haag 1954 ini menekankan tentang perlindungan benda budaya yang tidak boleh dibawa keluar dari wilayah aslinya oleh negara yang mengokupasi wilayah tersebut, ${ }^{31}$ kemudian jika konflik bersenjata telah berakhir maka benda budaya yang dibawa keluar dari wilayah aslinya harus dikembalikan kepada pihak yang memiliki otoritas. ${ }^{32}$ Artinya perlindungan benda budaya dalam protokol ini lebih menekankan kepada tindakan pencegahan kepada benda budaya yang terancam diambil dan diselundupkan ke luar negeri selama masa konflik bersenjata, dan memberikan kepastian perlindungan untuk benda budaya yang memang sengaja dikirim keluar wilayah aslinya untuk menghindari dari kehancuran akibat konflik bersenjata.

b. Protokol Kedua Den Haag 1954 Terkait Perlindungan Benda Budaya pada Masa Konflik Bersenjata 1999

Protokol kedua dibuat sebagai jawaban atas kegusaran atas konflik yang terjadi di Yugoslavia dimana banyak benda budaya yang hancur. Hal ini mendorong komunitas internasional untuk mengubah dan memodifikasi Konvensi Den Haag 1954 sebagai konsekuensinya. ${ }^{33}$ Protokol 1999 menghasilkan beberapa perubahan fundamental terhadap perlindungan benda budaya pada masa konflik bersenjata, salah satunya dengan menambahkan pengertian Perlindungan yang ditingkatkan (Enhanched Protection). Perlindungan yang ditingkatkan merupakan suatu aturan baru yang mengisyaratkan bahwa benda budaya yang telah memiliki perlindungan sebagai benda budaya dapat ditingkatkan perlindunganya. Perlindungan yang dipertinggi hanya dapat diberikan kepada benda budaya yang memiliki kriteria sebagai berikut: ${ }^{34}$

1) Benda budaya tersebut merupakan warisan yang memiliki nilai keluhuran budaya, yang warisannya sangat penting bagi umat manusia;

\footnotetext{
Roger O'Keefe, 2006, The Protection of Cultural Property in Armed Conflict, Cambridge University press, New York, hlm.199-200. Pasal 1, Protocol to the Convention for the Protection of Cultural Property in the Event of Armed Conflict (1954).

Ibid, Pasal 5.

Jiri Toman, 2009, Cultural Property in War; Improvement in Protection, Commentary on the 1999 Second Protocols to the Hague Convention 1954 for the Protection in the Event of Armed Conflict, UNESCO Publishing, Paris, hlm. 21.

34 Pasal 10, Second Protocol to the Hague Convention of 1954 for the Protection of Cultural Property in the Event of Armed Conflict (1999).
} 
2) Telah dilindungi oleh hukum nasional yang mengakuinya sebagai benda budaya yang sangat penting dan telah diberikan perlindungan dalam tingkat yang tertinggi;

3) Tidak berada atau dekat objek militer, pihak yang memiliki benda budaya tersebut harus mengumumkan bahwa benda budaya tersebut tidak akan digunakan sebagai bagian dari kepentingan militer.

c. Perubahan Status Benda Budaya pada Protokol 1999

Protokol kedua juga menjelaskan bahwa benda budaya yang sudah mendapatkan status enhanched protection dapat dicabut atas dasar benda budaya tersebut sudah tidak masuk persyaratan dalam pengaturan pemberian status enhanhed protection oleh Protokol 1999. Kehilangan status tersebut dapat terjadi karena adanya perubahan status benda budaya yang menjadi objek militer pada masa konflik bersenjata. Protokol 1999 mensyaratkan bahwa benda budaya yang akan dicabut status enhanced protection nya harus berkomunikasi langsung dengan Komisaris-Jendral. Dalam Protokol 1999 negara pihak harus bisa memastikan bahwa benda budaya yang akan dicabut statusnya haruslah mendapatkan otorisasi dari otoritas terkait. Mengingat didalam Pasal 28 pelanggaran yang dilakukan dengan mengabaikan persyaratan dari Pasal 11 di Protokol ini akan dikenai sanksi berupa hukuman pidana kepada setiap individu yang memerintahkan penyerangan tersebut.

Pihak yang berhak untuk melakukan pencabutan status enhanced protection dilakukan oleh panglima tertinggi didalam operasi militer. ${ }^{35}$ Jika ditelisik hal ini akan sedikit berbeda dengan persyaratan siapa yang berhak menetapkan status bahwa benda budaya tersebut dicabut dalam Konvensi Den Haag 1954 adalah komandan divisi atau yang lebih tinggi. Perkembangan di dalam Protokol 1999 mengenai siapa yang berhak mencabut status dan berhak melakukan penyerangan terhadap benda budaya memang mengalami sedikit penyesuaian. Selama masa perundingan pembuatan proposal dari Protokol 1999 negara-negara yang terlibat dalam perancangan proposal tersebut menyerukan untuk membahas lebih dalam, delegasi Israel menyampaikan bahwa yang berhak mengambil keputusan ialah komandan tertinggi setingkat divisi, hal ini merujuk kepada Konvensi Den Haag 1954. Kemudian Turki menyerukan, bahwa yang berhak mengambil keputusan tersebut haruslah dilakukan oleh 'setinggi mungkin' pada level pusat komando nasional. ${ }^{36}$ Kemudian delegasi ICRC menyampaikan komentarnya terkait usulan-usulan dari para delegasi negara-negara yang hadir:

"The Second Protocol seeks to tighten these conditions, but an effort to change the relative duty of notice into an absolute duty and a concomitant effort, supported by the ICRC, to have the decision to attack taken at the highest level of government failed. It would indeed make sense to have the decision taken at the highest level of government because of the political implications thereof. Several delegates, however, argued against this proposal. While they recognized that in some countries such a decision would probably be taken at the highest level of government, for example if the Head of State is the Commander-in- 
Chief of the armed forces, they felt that the political structures of countries around the world were too diverse to impose such an obligation. Hence, the Second Protocol requires that an attack be ordered at the highest operational level of command". 37

Perubahan status benda budaya tersebut didalam Protokol kedua memang diizinkan selama kepentingan militer untuk menggunakan benda budaya tersebut memang menjadi pilihan terakhir dan pilihan satu-satunya. Namun dalam Protokol kedua ini menjelaskan kembali bahwa yang berhak memeberikan instruksi dan mencabut status benda budaya yang dipertinggi tersebut tidak lagi dalam level komandan divisi, namun dalam hal lain jika keadaan sangat tidak memungkinkan dapat diputuskan oleh tingkat komando yang lebih rendah. ${ }^{38}$ Tetapi pada keadaanyangnormal komando tertinggi dalam sebuah militer yang berhak memutuskan hal tersebut. Hal ini memepertimbangkan bahwa, setiap keputusan yang diambil akan memiliki konsekuensi hukum dimasa depan.

\section{Instrumen Hukum Nasional Mengenai Perlindungan Benda Budaya}

a. Undang-Undang Nomor 11 Tahun 2010 tentang Cagar Budaya

Begitu besarnya dunia internasional merespon perlindungan terhadap benda cagar budaya sehingga banyak peraturanperaturan yang dibuat semata-mata hanya untuk melindungi benda cagar budaya dimasa konflik bersenjata. Indonesia pun seharusnya mengikuti langkah tersebt guna melindungi benda cagar budaya yang tersebar diseluruh wilayah Indonesia, yang banyak diantaranya memiliki peranan yang teramat besar bagi perkembangan umat manusia khususnya dikawasan Indonesia. Pemerintah melalui KEPPRES No. 243 tahun 1966 menyatakan keikutsertaannya dalam meratifikasi Konvensi Den Haag 1954 tanpa suatu keberatan apapun. Tahun 1992 dan 2010 Indonesia akhirnya mengeluarkan Undang-Undang nomor 5 Tahun 1992, dan Undang-Undang nomor 11 Tahun 2010, sebagai implementasi dari dikeluarkannya KEPRES No.234 Tahun 1966.

b. Pengertian Benda Budaya Menurut Undang-Undang Nomor 11 Tahun 2010 tentang Cagar Budaya

Benda cagar budaya adalah warisan budaya bersifat kebendaan berupa benda cagar budaya, bangunan cagar budaya, struktur benda budaya, situs benda budaya, dan Kawasan cagar budaya di darat dan atau di air yang perlu dilestarikan keberadaannya karena memiliki nilai penting bagi sejarah, ilmu pengetahuan, pendidikan, agama dan atau kebudayaan melalui proses penetapan. ${ }^{39}$ Warisan budaya yang dimaksud adalah warisan bagi seluruh umat manusia, karena kebudayaan adalah hasil pemikiran manusia yang mengandung nilai-nilai universal. ${ }^{40}$ Dengan demikian warisan benda cagar budaya tidak mengenal adanya batasan terhadap suku, ras, agama, golongan dan politik, karena memiliki sifat yang penting yaitu warisan bagi seluruh umat manusia.

Tidak semua benda purbakala dapat dikategorikan sebagai benda cagar budaya, hal ini merujuk kepada Pasal 1 dalam Undang-Undang No. 11 Tahun 2010, yakni benda cagar budaya ditetapkan

9 Pasal 1 ayat (2) Undang-Undang Nomor 11 Tahun 2010 tentang Cagar Budaya (Lembaran Negara Tahun 2010 Nomor 130, Tambahan Lembaran Negara Nomor 5168).

40 Undang-Undang Nomor 11 Tahun 2010 tentang Cagar Budaya (Lembaran Negara Tahun 2010 Nomor 130, Tambahan Lembaran Negara Nomor 5168). 
melalui proses penetapan oleh bupati, walikota, gubernur melalui rekomendasi dari tim ahli cagar budaya sesuai dengan kewenangannya. ${ }^{41}$ Pemeringkatan tersebut dilakukan sesuai dengan kewenangan masing-masing perangkat, Menteri untuk menetapkan peringkat Nasional, Gubernur untuk menetapkan peringkat tingkat Provinsi, Walikota atau Bupati untuk pemeringkatan tingkat Kota dan Kabupaten. Pengusulan cagar budya dengan peringkat nasional menjadi situs warisan budaya dunia merupakan kewenangan Menteri kebudayaan sepenuhnya. ${ }^{42}$ Maka hal tersebut seluruh benda, bangunan, situs yang telah mendaptkan status cagar budaya dan ODCB atau Objek Diduga Cagar Budaya, wajib didaftarkan dalam sistem registrasi nasional cagar budaya. ${ }^{43}$

Undang-Undang No. 11 Tahun 2010 menjelaskan bahwa benda cagar budaya yang belum ditetapkan akan disebut ODCB yang mana perlindungan hukumnya sama dengan benda cagar budaya yang telah ditetapkan sebagai benda cagar budaya, sampai dikemudian hari terbukti tidak memenuhi unsur-unsur untuk ditetapkan sebagai benda cagar budaya, maka status ODCB tersebut akan dicabut. ${ }^{44}$ ODCB sebenarnya tidak termaksud benda cagar budaya yang dilindungi dalam Konvensi Den Haag 1954 jika benda cagar budaya tersebut tidak dilihat sebagai bagian dari Monuments, dalam pengerrtiannya sendiri kata Monuments seringkali diartikan sebagai dengan Cultural
Properties yang bersifat kebendaan.

Terdapat sebanyak lima jenis benda cagar budaya, yakni: berupa benda, bangunan, struktur, situs, dan kawasan. Situs dan kawasan merupakan bagian dari cagar budaya yang bersifat ruang contohnya seperti sistem subak di provinsi Bali, dan yang tiga lainnya merupakan benda cagar budaya yang dapat diamati, dipegang, diukur, dan dipindahkan dari tempat asalnya. Menurut sifat keruangannya terapat dua jenis yaitu benda cagar budaya yang dapat dipindahkan atau moveable Properties dan benda cagar budaya yang tidak memungkinkan untuk dipindahkan atau immovable Properties. ${ }^{45}$

c. Registrasi Benda Budaya dalam Instrumen Hukum Nasional

Setiap benda budaya yang telah ditemukan oleh masyarakat dan atau ahli kepurbakalaan maka benda budaya tersebut wajib untuk diregistrasikan kedalam register nasional. Register nasional menjadi penting dikarenakan akan sangat memudahkan untuk melakukan identifikasi terhadap benda budaya dan juga untuk melakukan kategorisasi mana benda budaya yang harus ditingkatkan statusnya untuk dapat didaftarkan kepada UNESCO. Sistem registrasi nasional terkait benda budaya akan menampung data-data yang detil mengenai benda budaya tersebut, seperti; keterangan nama pemilik, nama daerah, alamat, jenis, dan nama objek atau ruangan, ukuran, deskripsi mengenai benda budaya tersebut, koordinat, peringkat, dan tahun penetapan. ${ }^{46}$ Sistem registrasi tersebut

${ }^{41}$ Pasal 1 angka 1 Undang-Undang Nomor 11 Tahun 2010 tentang Cagar Budaya (Lembaran Negara Tahun 2010 Nomor 130, Tambahan Lembaran Negara Nomor 5168).

42 Pasal 45 Undang-Undang Nomor 11 Tahun 2010 tentang Cagar Budaya (Lembaran Negara Tahun 2010 Nomor 130, Tambahan Lembaran Negara Nomor 5168).

43 Pasal 37 Undang-Undang Nomor 11 Tahun 2010 tentang Cagar Budaya (Lembaran Negara Tahun 2010 Nomor 130, Tambahan Lembaran Negara Nomor 5168).

44 Pasal 37 Undang-Undang Nomor 11 Tahun 2010 tentang Cagar Budaya (Lembaran Negara Tahun 2010 Nomor 130, Tambahan Lembaran Negara Nomor 5168).

45 Pasal 37 Undang-Undang Nomor 11 Tahun 2010 tentang Cagar Budaya (Lembaran Negara Tahun 2010 Nomor 130, Tambahan Lembaran Negara Nomor 5168).

46 Pasal 28 Undang-Undang Nomor 11 Tahun 2010 tentang Cagar Budaya (Lembaran Negara Tahun 2010 Nomor 130, Tambahan Lembaran Negara Nomor 5168). 
juga dilengkapi logo sebagai tanda benda cagar budaya.

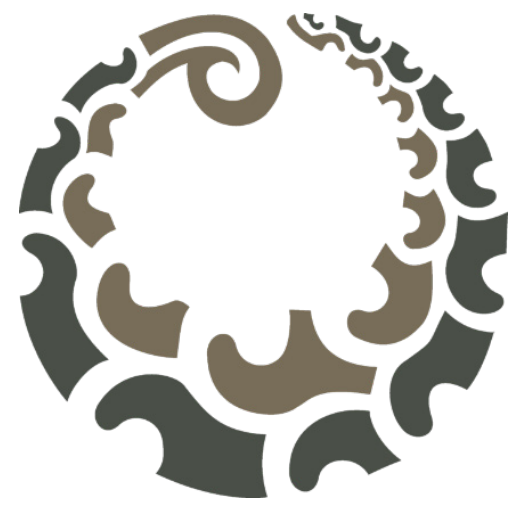

Gambar 2. Lambang Penanda Cagar Budaya di Indonesia

Sumber: Sistem Registrasi Nasional, Kementerian Pendidikan dan Kebudayaan, 2019.

\section{Urgensi Perlindungan Benda Cagar budaya pada Masa Konflik Bersenjata bagi Indonesia}

Setelah membahas berbagai peraturan mengenai perlindungan benda cagar budaya dari sisi instrumen hukum internasional dan nasional, arktikel ini berpendapat bahwa Indonesia memerlukan suatu peraturan khusus yang dibuat untuk melindungi benda budaya pada masa konflik bersenjata. Sebagai fakta bahwa Indonesia memiliki banyak sekali peninggalan benda budaya didalamnya, dan peraturan yang ada saat ini yaitu Undang-Undang No. 11 Tahun 2010, dirasa belum mencakup kebutuhan yang sangat urgen bagi Indonesia. Seperti telah dibahas didalam Konvensi Den Haag 1954 bahwa negara-negara yang telah menjadi peserta dari Konvensi tersebut memiliki dua kewajiban utama yaitu, pada masa damai dan pada masa konflik bersenjata itu terjadi.

Kewajiban negara pada masa damai ialah, membuat peraturan, mensosialisasikan, melakukan diseminasi terhadap semua aspek yang menjadi garda terdepan untuk menjaga benda budaya yaitu; militer, kepolisian, pertahanan sipil, badan SAR, pemadam kebakaran, aparatur pegawai negeri sipil, hingga masyarakat, agar mengetahui apa yang harus dilakukan terhadap benda budaya yang telah memiliki lambang perlindungan umum maupun khusus pada masa konflik bersenjata nantinya. Jika seluruh aspek yang terkait ini tidak berjalan sebagaimana fungsinya dikhawatirkan benda budaya yang sudah memiliki status perlindungan umum dan khusus dapat terancam hilang dan musnah akibat kurangnya kecakapan dalam perlindungan benda budaya, terutama pengenalan kepada militer mengenai benda budaya harus dihormati dan tidak boleh diserang terkecuali dalam kondisi-kondisi tertentu dimana militer memang diizinkan untuk menggunakan dan menyerang benda budaya sebagai bagian dari pertahanan. Jika hal tersebut terjadi dan dalam hal ini benda budaya tersebut musnah maka akan menimbulkan konsekuensi hukum dikemudian hari kepada individu yang memerintahkan penggunaan atau penyerangan terhadap benda budaya tersebut.

Perbedaan yang mendasar antara benda budaya yang telah mendapatkan perlindungan umum dan khusus dan yang tidak memiliki perlindungan adalah, penggunaanya pada masa konflik bersenjata sebagai basis militer harus diputuskan melalui komandan divisi atau yang lebih tinggi, namun peraturan tersebut telah diamandemen melalui Protokol 1999 yakni penggunaan benda budaya pada masa konflik bersenjata harus melalui keputusan komando tertinggi dalam militer, jika diimplementasikan di Indonesia maka akan menjadi bagain dari tugas panglima TNI sebagai pucuk pimpinan tertinggi dalam militer. ${ }^{47}$ Wewenang tersebut secara langsung dapat menyelamatkan benda budaya dari kehancuran total, karena persyaratannya yang harus melalui mekanisme ditingkat pusat, berbeda dengan benda budaya yang tidak mendapat perlindungan internasional, maka penggunaan benda budaya

\footnotetext{
47 Saurip Kadi, 2008, Megutamakan Rakyat- WawancaraMayor Jendral TNI oleh Liem Siok Lan, Yayasan Obor Indonesia, Jakarta, hlm 147.
} 
tersebut untuk kepentingan militer bisa ditetapkan melalui mekanisme yang tidak terlalu sulit, dalam hal ini pimpinan regu militer dapat menerapkan kebijakan semacam itu. Sementara itu penggunaan enchanched protection belum menjadi bahan acuan proses pendaftaran benda budaya. System pendaftaran pemeringkatan yang digunakan oleh pemerintah Indonesia tidak dikenal dalam hukum humaniter internasional, akibatnya ketika konflik bersenjata terjadi di Indonesia, benda budaya tersebut tidak mendapatkan perlindungan yang memadai. Dengan demikian Indonesia harus memberikan peraturan yang lebih rinci mengenai benda budaya baik melalui amandemen UndangUndang No 11 tahun 2010, maupun membuat Undang-Undang impelentasi dari Konvensi yang sudah diratifikasi.

Lebih jauh proses registrasi pada UndangUndang No. 11 Tahun 2010 tidak mengikuti aturan yang terdapat pada Konvensi Den Haag 1954. Dalam Undang-Undang No. 11 Tahun 2010 tidak mencantumkan sama sekali mengenai perlindungan benda budaya umum dan khusus. jika dilihat lebih teliti Undang-Undang No.11 Tahun 2010 hanya berbicara proses pendataan beradasarkan sistem pemeringkatan dari tingkat kabupaten hingga nasional. Lebih jauh lagi pendaftaran dengan sistem pemeringkatan tersebut tidak berbicara sama sekali mengenai perlindungan pada masa konflik bersenjata, hanya sebatas pada pemberian status register benda budaya berdasarkan wilayah dan kewenangan dari suatu daerah. ${ }^{48}$ Dengan demikian Undang-Undang No 11 Tahun 2010 menjadi tidak sinkron dengan perjanjian yang sudah diaksesi oleh Indonesia yaitu Konvensi Den Haag 1954.

Seperti disebutkan diatas bahwa Protokol kedua tahun 1999 dari Konvensi Den Haag 1954 merupakan pemutakhiran isi dari Konvensi tersebut. Banyak hal-hal yang baru terkandung dalam protokol tersebut, seperti peraturan mengenai enhanced protection peraturan benda budaya yang dibawa keluar negeri, serta kewajiban untuk pengembaliannya setelah konflik bersenjata selesai, dan sanksi yang diterapkan kepada individu yang melanggar isi dari protokol tersebut. Dengan demikian menjadi kewajiban bagi Indonesia untuk mengaksesi Protokol kedua 1999 tersebut, dan membuat peraturan yang lebih layak mengenai perlindungan benda budaya pada masa konflik bersenjata.

Merujuk kepada Protokol 1999 yang sudah lebih rinci terkait perlindungan benda budaya, karena pada konvensi Den Haag 1954 perlindungan benda budaya. Perlindungan yang dimaksudkan adalah perlindungan terhadap benda budaya yang bersifat "Moveable Properties" yang berada di luar teritori nya, dalam hal ini diartikan sebagai benda budaya hasil dari okupasi militer melalui permohonan secara langsung "By Request". ${ }^{49}$ Mengingat pada era kolonial banyak benda budaya Indonesia yang dibawa keluar negeri dan bukan persoalan yang mustahil terjadi lagi ketika kelak konflik bersenjata timbul maka perlindunganya tidak sebatas hanya yang berada di teritorinya, namun juga yang berada diluar teritorinya. Dengan demikian enhanced Protection menrinci lebih detil dari perlindungan khusus yang terbatas pada wilayah teritori sebuah negara, dengan hal tersebut Indonesia sesegera mungkin untuk menandatangani dan meratifikasi Protokol 1999 dikarenakan banyaknya benda budaya yang bergerak maupun yang tidak bergerak yang dimiliki Indonesia dan sebagai bagian dari upaya perlindungan benda cagar budaya pada masa damai.

\section{Implementasi Perlindungan Benda Cagar Budaya pada Masa Damai melalui Pem- bentukan Panita Penetapan (PANTAP)}

Suatu peraturan khusus yang melindungi benda cagar budaya ketika masa konflik bersenjata

\footnotetext{
48 Bab VI Pemilikan dan Penguasaan Undang-Undang Nomor 11 Tahun 2010 tentang Cagar Budaya (Lembaran Negara Tahun 2010 Nomor 130 , Tambahan Lembaran Negara Nomor 5168)

49 Jiri Toman, Op.cit., hlm. 207.
} 
bagi Indonesia menjadi mutlak perlu, karena hingga saat ini baru sebanyak empat situs cagar budaya yang baru terdaftar di UNESCO. Jika kita melihat dari ujung barat hingga ujung timur Indonesia terdiri dari berbagai macam budaya yang masingmasing memiliki kekhasannya masing-masing. Dengan demikian berangkat dari kesadaran tersebut dibentuklah Panitia Penetapan (selanjutnya disebut PANTAP) dalam rangka menyusun rancangan persiapan Undang-Undang tentang Perlindungan Benda Cagar Budaya pada Masa Konflik Bersenjata yang anggotanya terdiri dari Kementerian Hukum dan HAM, Kementerian Pertahanan, Kementerian Dalam Negeri, Palang Merah Indonesia, Kementerian Sosial, Tentara Nasional Indonesia, Kementerian Luar Negeri, Kementerian Pendidikan dan Kebudayaan, ICRC, dan Universitas.

PANTAP bukan merupakan hal yang baru. Perancis sudah terlebih dahulu membentuk PANTAP serupa untuk melindungi benda cagar budaya yang ada di Perancis. PANTAP perancis berada dibawah Lembaga Commison Nationale Consultative des Droit de L'homme (CNCDH). Peran $\mathrm{CNCDH}$ yakni memberikan rekomendasi kepada pemerintah Perancis terkait isu-isu humaniter, seperti memberi masukan kepada pemerintah Perancis untuk segera meratifikasi Protokol 1999 pada tahun 2015 yang ditindak lanjuti dengan pengaksesian oleh Perancis pada tahun 2017, sebagai output dari tugas PANTAP Perancis. PANTAP perancis juga melakukan penegakan implementasi terhadap isi dari Protokol 1999 dan melatih personil militer Perancis tentang perlindungan benda cagar budaya. Melihat apa yang sudah dilakukan oleh PANTAP Perancis maka model tersebut juga seharusnya bisa dilakukan di Indonesia. ${ }^{50}$

Tugas PANTAP di Indonesia yaitu ialah memberikan rekomendasi kepada Kementerian Hukum dan HAM perihal kebijakan pemerintah yang berkenaan dengan konvensi Jenewa 1949 dan protokol tambahan 1977, dan peraturan internasional lainnya yang berkenaan dengan hukum humaniter. Langkah yang dilakukan PANTAP dengan merumuskan rancangan UndangUndang Perlindungan Benda Cagar Budaya Pada Masa Konflik Bersenjata sejalan dengan apa yang diamanahkan dalam Pasal 3 Konvensi Den Haag 1954, yaitu negara peserta pada masa damai mempersiapkan hal-hal yang diperlukan untuk melindungi benda cagar budayanya. Hal ini sangat penting untuk segera dilakukan mengingat Indonesia juga belum memiliki sebuat peraturan yang khusus mengatur tentang perlindungan benda cagar budaya pada masa konflik bersenjata. Undang-Undang No. 11 tahun 2010 seperti yang dijelaskan pada bab sebelumnya hanya memuat peraturan-peraturan umum yang masih menimbulkan perdebatan seperti apa yang dimaksud bencana dan bagaimana penanggulangannya. ${ }^{51}$

PANTAP juga tidak terbatas membuat rencana rancangan Undang-Undang tentang perlindungan benda cagar budaya, namun juga melingkupi kegiatan pelatihan hukum humaniter bagi tenaga pengajar, pegawai dan jurnalis, diseminasi hukum humaniter di beberapa provinsi di Indonesia. Pada tahun 2017 PANTAP melakukan koordinasi antar instasi pemerintahan dalam usaha mengesahkan aturan hukum mengenai lambang kepalangmerahan melalui Undang-Undang Nomor 1 Tahun 2018 tentang Kepalangmerahan, memperkuat kududukan Palang merah Indonesia, melakukan kegiatan diseminasi bersama ICRC dan kalangan akademik bertemakan isu hukum humaniter, mengkoordinasi rencana pembentukan rancangan peraturan pelaksanaan Undang-Undang kepalangmerahan, merancang RUU tentang perlindungan benda cagar budaya pada masa konflik bersenjata, sesi diseminasi hukum humaniter kepada pejabat pemerintahan di pusat maupun di daerah dengan isu tematik: perlindungan benda cagar budaya,

\footnotetext{
50 PANTAP Humaniter; “Dalam Rangka Pembuatan Rancangan Undang-Undang tentang Perlindungan Benda Cagar Budaya pada Masa Konflik Bersenjata".

51 Ibid.
} 
penggunaan lambang.

Langkah-langkah yang diambil oleh PANTAP dalam pembuatan Rancangan Undang-Undang yaitu terbagi dalam tiga kategori: 1) Menyeluruh: Prosedur perlindungan properti akan melibatkan berbagai pihak, tidak hanya Pemerintah namun juga ICRC dan UNESCO, serta juga kelompok adat masyarakat hendaknya menyusun prosedur yang efisien jika terjadi pelanggaran; 2) Prosedur: Mencakup proses pencegahan, penjagaan, perijinan, dan pemberian lisensi kepada pihak ketiga. Kemudian prosedur penanganan pelanggaran hingga prosedur persidangan dan hukuman bagi pelaku; 3) Militer: Ketentuan dilapangan tentu akan melibatkan militer, apalagi jika berkaitan perlindungan benda cagar budaya pada masa konflik bersenjata. Sehingga pembinaan terhadap militer tidak berdiri sendiri namun juga berdiri beriringan dengan elemen pemerintahan terkait. ${ }^{52}$

\section{Kesimpulan}

Kewajiban negara untuk melindungi benda budayanya pada masa damai adalah suatu keharusan. Konflik bersenjata merupakan hal yang tidak diharapkan namun ancaman konflik bersenjata dapat terjadi kapanpun dan dimanapun. Mengingat Indonesia adalah negara yang memiliki warisan benda budaya yang sangat banyak yang sebagian diantaranya merupakan warisan kebudayaan bagi umat manusia yang sangat penting, maka keberadaanya perlu dijaga dan dilestarikan. Konvensi Den Haag 1954 dalam hal ini sudah jelas mengamanatkan bahwa negara pihak pada masa damai harus mempersiapkan perlindungan benda budayanya dengan berbagai macam cara, seperti; membuat berbagai sosialisasi dan diseminasi terhadap pihak-pihak yang memiliki peran langsung dalam pelestarian benda budaya dan dalam kemiliterannya, agar jika terjadi konflik bersenjata pihak-pihak tersebut tahu apa yang harus dilakukan mengacu kepada regulasi yang melindungi benda budaya tersebut.

Indonesia dalam hal ini harus dengan sesegera mungkin mengaksesi protokol kedua 1999 dari Konvensi Den Haag 1954 dikarenakan Protokol tersebut merupakan pemutakhiran dari Konvensi Den Haag 1954. Protokol 1999 menambahkan kriteria enhanced protection, pencegahan benda budaya yang dirampas oleh pasukan musuh ketika konflik bersenjata, dan mengatur pengembalian benda budaya hasil rampasan ketika konflik bersenjata telah selesai.

Undang-Undang No. 11 Tahun 2010 dirasa belum cukup untuk melindungi benda budaya pada masa konflik bersenjata, walaupun dalam UndangUndang tersebut merumuskan perlindungan benda budaya dari bencana, namun akan timbul pertanyaan bencana macam apa yang dimaksudkan, dan bagaimana penangananya. Selain itu UndangUndang No 11 Tahun 2010 tidak menyebutkan pelepasan status perlindungan benda budaya ketika masa konflik bersenjata, melihat kepada Konvensi Den Haag 1954 dan Protokol kedua 1999 dari Konvensi Den Haag 1954 dengan jelas mengatur bahwa perlindungan benda budaya tidak bersifat absolut namun dapat dicabut sewaktu-waktu jika benda budaya tersebut dibutuhkan oleh militer sebagai bagian dari pertahanan.

Pembuatan Undang-Undang baru yang mengatur perlindungan benda budaya pada masa konflik bersenjata sangat diperlukan bagi Indonesia. Tujuan dalam Undang-Undang tersebut jika suatu saat terjadi konflik bersenjata di Indonesia kerusakan yang mengancam benda budaya diharapkan dapat diminimalisir, karena adanya peraturan yang jelas kapan benda budaya dapat diserang dan tidak boleh diserang sebagai objek militer. Diharapkan Undang-Undang perindungan benda budaya pada masa konflik bersenjata dapat memasukan pengaturan tentang benda budaya yang dipertinggi atau enhanced protection. Benda budaya yang dipertinggi jelas adalah kunci utama 
dalam perlindungan benda budaya dikarenakan benda budaya yang memiliki perlindungan yang dipertinggi tidak bisa dijadikan objek militer atau diserang begitu saja, yang membedakannya dengan objek sipil lain adalah terkait bagaimana proses pelepasan perlindungan tersebut harus diputuskan melalui Panglima TNI sebagai komandan utama dari angkatan bersenjata di Indonesia.

\section{DAFTAR PUSTAKA}

\section{A. Buku}

Chamberlain, Kevin, 2006, Casualties of Armed Conflict: Protecting Cultural Property. In Yearbook of Humanitarian Law Volume 17, 2014, compiled by Terry D. Gill (eds) Asser Press, The Hague.

Kadi, Saurip, 2008, Megutamakan RakyatWawancaraMayor Jendral TNI oleh Liem Siok Lan, Yayasan Obor Indonesia, Jakarta.

O'Keefe, Roger, 2006, The Protection of Cultural Property in Armed Conflict, Cambridge University press, New York.

Toman, Jiri, 2009, Cultural Property in War; Improvement in Protection, Commentary on the 1999 Second Protocols to the Hague Convention 1954 for the Protection in the Event of Armed Conflict, UNESCO Publishing, Paris.

\section{B. Artikel Jurnal}

Driver, Mark C., "The Protection of Cultural Property During Wartime", Review of European Community and International Environmental Law, Vol. 9, Issue 1, April 2003.

Schipper, Friederich T, et al., "A Concise Legal History of the Protection of Cultural Property in the Event of Armed Conflict and a Comparative Analysis of the 1935 Roerich Pact and the 1954 Hague Convention in the Context of the Law of War", Archaeologies: Journal of the World Archeological Congress, Vol.9, Issue 1, April 2013.

\section{Internet}

DITPCBM, "Cagar Budaya", https://kebudayaan. kemdikbud.go.id/ditpcbm/cagar-budaya/, diakses 10 Januari 2019.

DITPCBM, "Diklat PPNS Cagar Budaya 2019: Kaitannya Dengan Perlindungan Cagar Budaya di Indonesia", https://kebudayaan. kemdikbud.go.id/ditpcbm/diklat-ppnscagar-budaya-2019-kaitannya-denganperlindungan-cagar-budaya-di-indonesia/, diakses 26 November 2019.

Fakultas Hukum Universitas Indonesia, "Perlindungan hukum terhadap cagar budaya di Indonesia”, http://law.ui.ac.id/v3/4385-2/, diakses 8 Oktober 2018.

ICC Document (2017), "Situation in the Republoc of Mali in the Case of the Prosecutor v. Ahmad Al-faqi Al Mahdi", https://www.icccpi.int/CourtRecords/CR2017_05117.PDF, diakses 9 Oktober 2018.

Permanasari, Arlina, "Indonesia dan konvensi Den Haag 1954", https://arlina100.wordpress. com/2008/12/18/indonesia-dan-konvensiden-haag-1954/\#more-740, diakses 9 Oktober 2018.

UNESCO, "Why is it necessary to protect cultural property in the event of armed conflict and/or occupation", http://www.unesco.org/new/en/ culture/themes/armed-conflict-and-heritage/ convention-and-protocols/frequently-askedquestions/\#c287372, diakses 8 Oktober 2018.

\section{Peraturan Perundang-undangan}

Undang-Undang Nomor 11 Tahun 2010 tentang Cagar Budaya (Lembaran Negara Tahun 2010 Nomor 130, Tambahan Lembaran Negara Nomor 5168). 


\section{E. Dokumen Lain}

1899 the Hague Convention.

1907 the Hague Convention No. IV; laws and customs of war on land.

1935 Roerich Pact and the Banner of Peace.

Konvensi Tentang Perlindungan Benda Cagar Budaya Pada Masa Konflik Bersenjata DenHaag, 1954.

Bahan Seminar PANTAP Humaniter; Dalam
Rangka Pembuatan Rancangan UndangUndang tentang Perlindungan Benda Cagar Budaya pada Masa Konflik Bersenjata.

Protocol to the Convention for the Protection of Cultural Property in the Event of Armed Conflict (1954).

Second Protocol to the Hague Convention of 1954 for the Protection of Cultural Property in the Event of Armed Conflict (1999). 